by the system used previously, was issued in December 1949, and copies can be obtained ( $5 s$., post free) from the present honorary secretary of the Diagrams and Data Sub.Committee of the Hospital Physicists' Association, D. E. A. Jones, Mount Vernon Hospita], Northwood, Middlesex.

\section{Moa Discoveries}

THE Association of Friends of the Canterbury Museum, Christchurch, New Zealand, has produced an interesting guide-book describing how in 1937 moa bones were found at Pyramid Valley, fifty miles from Christchurch, and how the site has since been developed. After two years excavation the total of more or less complete and clearly individual moa skeletons stood at fifty, 17 of them being Dinornis maximus, 3 Pachyornis elephantopus, 3 Euryapteryx gravis, and 27 Emeus crassus; these are the heavylimbed giant grazing moas. In addition to bones were found remains of still undigested meals with recognizable seeds and severed lengths of twigs and coaree grasses, closely packed among the gizzard stones. The few crops examined have revealed no traces of the koromiko (Hebe), the widespread shrub universally associated with the moa in Maori legend. On an average, each gizzard contained 220 stones weighing $5 \frac{1}{2} \mathrm{lb}$. These discoveries have been of great assistance in clarifying the systematics of the moas. Copies of the well-illustrated guide may be obtained from the Museum, price $2 s .6 d$.

\section{Rock-Shelter Art in South Africa}

The June 1949 issue of the South African Archoological Bulletin contains, among other articles, one by the Abbé Henri Breuil on "Some Foreigners in the Frescoes on Rocks in Southern Africa.". The Abbé Breuil is convinced that a number of the human beings figured in rock-shelters belong to non-African races, presumably prospectors who came to explore the country. At various periods such prospectors, coming from the north, did penetrate parts of Africa, and we have accounts of them. But whether they really penetrated so far as South Africa is a real problem. The paintings at Impey's Cave certainly recall others found in a rock-shelter in North Africa. But has enough study been given to Bantu art and its possibilities? In this connexion, the studies of Canon Edward Paterson of Cyrene, Southern Rhodesia, who deals with a number of Bantu children, should be mentioned. He maintains that white-man influence has played no part in their drawings, yet these are extremely varied and sometimes quite naturalistic. The same number of the Bulletin contains a note, written by A. J. H. Goodwin, of a painted fishing scene from East Griqualand ; fishing scenes are none too common in this art. There is also a note by R. J. Mason on some glass implements with Wilton associations.

\section{Scientific Manuscripts from Scandinavia}

Throughout Scandinavia most original scientific work is now published in the English language. Some authors write in English and others have their work translated locally; but in many cases it is advisable to obtain the services of an English-speaking man of science to check the manuscript. A most desirable course would be for such material to be checked by an English-speaking specialist who is working on almost identical lines and thereby has a natural interest in the work. The British Council has, therefore, initiated a scheme whereby it will endeavour to place each manuscript which has been submitted through its offices in Scandinavia with a scientific worker in Great Britain who is likely to have an interest in the subject in question and can carry out the checking. In general, the Scandinavians are willing to pay reasonable fees for such services, and the British Council has arranged to undertake the currency conversion for payment in sterling. The Council itself will make no charge for its services.

\section{East African Industrial Research Board : Report for 1948}

THE sixth annual report of the East African Industrial Research Board (pp. 12; Nairobi, 1949 ; 1s. 6d.), which became a department of the East African High Commission on January 1, 1948, covers the year ended December 31, 1948. Investigations continued on various branches of ceramic technology, such as bricks and roofing tiles, domestic pottery and refractories, the extraction of undried pyrethrum flowers, the processing of silico-phosphatic fertilizers and the treatment of waste waters from the decortication of sisal. The polluting character of the waste waters and the size of biological filter required to treat them have been considerably reduced by dry decortication of the leaf and then washing the fibre alone. Promising results have been obtained in the treatment of waste waters from processing coffee. A list of technical publications is appended.

\section{"Mercury Tube Effect"}

REFERRING to the communication under this title by Dr. J. O'M. Bockris and Dr. R. Parsons in Nature, 160, 232 (1947), Prof. William MacNevin, of the Ohio State University, and Earl W. Balis have directed attention to a paper of theirs entitled "Deviations between Observed and Calculated Polarographic Diffusion Currents" (J. Amer. Chem. Soc., 65, 660 ; 1943). This contains a brief reference to the effect discussed by Messrs. Bockris and Parsons.

\section{Conference on the Older Stone Ages}

A CONFERENCE on "The Older Stone Ages : Recent Trends and Discoveries" will be held by the Prehistoric Society, in collaboration with the Institute of Archæology of the University of London, at the latter's address at Inner Circle, Regent's Park, London, N.W.1, during April 14-16. A number of papers will be read, and included in the programme will be discussions on "Geographical Aspects of the Older Palæolithic Cultures", in which Dr. C. McBurney, Mr. M. C. Burkitt, Mr. H. Kelley, Dr. K. Oakley and Mr. A. D. Lacaille will participate, and on "The Origin of the Upper Palæolithic in Eurcpe", which will be introduced by Mr. A. D. Lacaille. Further particulars can be obtained from the London Secretary, Mr. J. W. Brailsford, at the Department of British Antiquities, British Museum, London, W.C.1.

\section{Illuminating Engineering Society: Summer Meeting}

THE Illuminating Engineering Society will hold its summer meeting at Buxton, Derbyshire, during May 16-19. The technical papers will all be of a practical nature, and, in addition, two addresses will be given : by Dr. L. A. Sayce, of the Light Division of the National Physical Laboratory, on "Visual Deception" ; and by Mr. Ivar Folcker, chairman of the National Illumination Committee of Sweden and president of the Swedish Illuminating Engineering Society, who will speak about lighting in Sweden 